\title{
Family trends shaping the family business landscape
}

Joyce Kox] and Astrid Kramer

Organizations do not operate in a vacuum. Conditions and trends of the external environmental are pivotal as they shape the environment in which firms operate. Family businesses create a distinctive setting compared to non-family businesses as two systems can be distinguished, the family and the business, which are both embedded in the larger environment. Through family participation in management and ownership positions, the family is the dominant coalition in the firm. Research has shown that characteristics of the dominant coalition affect firm behavior and outcomes (Hambrick and Mason, 1984). In family firms, this implies that the family system resonates within the business system. A family, with its own structure, dynamics, and values and norms, has a large influence on the business.

Nevertheless, there is little understanding of how the family system affects the business. In addition, while the organization is not immune to changes in its environment, neither is the family. The family is embedded in society and consequently, societal trends alter family structure and dynamics. Given the intertwinement of the family and the business, changes in the family system are expected to have implications for the family business. Implications of family involvement may alter due to a change in family structure, events, and dynamics. Thus, when looking at important future issues for family business research, the family system cannot be overlooked.

The purpose of this chapter is to map important changes in the family and their implications for family businesses. This chapter is structured as follows. Firstly, the nature of the family system is explicated. Subsequently, significant trends in the family system and their implications in terms of management, ownership, and succession for family businesses are addressed. The chapter ends with concluding remarks and directions for future research (Table 1.1). 


\section{The nature of the family system}

In order to build knowledge about how the family and business system interact, understanding of the family is necessary. A family is a complex social system, characterized by dense relationships. Individuals are connected by strong emotional and loyalty bonds (Davis, 1983). Family ties are biological, historical, legal, and affectional in nature (Carr, 2000). The biological and legal aspect arises respectively through birth and marriage or adoption. Compared to other social systems, family relations are more enduring and involuntary (Klein and White, 1996). Only through impactful events such as marriage, death or birth a family system can be entered or exited (Carr, 2000).

Families can be characterized in terms of their structure, dynamics, and events. Structure refers to objective characteristics of the family and contains elements such as family composition, family size, generation, and the number of children. Family dynamics entail the nature and quality of interaction between family members (Olson, 2000). Examples are communication, cohesion, and parenting style. Structure and dynamics are interdependent as the family structure affects the nature of interaction and vice versa. Finally, family events, such as divorces, drive changes in the overall family structure and dynamics (Aldous, 1996).

A family consists of multiple individuals, who are part of multiple smaller and larger subsystems. On the dyadic level, a distinction can be made between within-generational (e.g. parent-parent, sibling-sibling) and between-generational (e.g. parent-child) relationships, and differ in terms of age, dependency, and authority (Eichelsheim et al., 2009). On the family level, a distinction between the nuclear and the extended family can be made. The nuclear family comprises parents and children, whereas the extended family also includes grandparents, uncles, nieces, and in-laws. The family system is embedded in the larger environment and therefore affected by external forces (Cox and Paley, 1997). Within the past few decades, trends in the broader environment have changed the family profoundly.

\section{Changing perspectives on having and raising children}

Due to the changing economic and social environment, families' perspectives on having and raising children have altered. This affects the nuclear family, 
in terms of structure and interactions. Below, the trends and implications are explicated in detail.

\section{Having less children at a later age}

Rising welfare and living conditions resulted in a decline in the number of children in developed countries. Globally, the average number of children a woman gives birth to dropped from 4.7 in 1950 to 2.4 in 2017, falling below the replacement level in most developed countries (Murray et al., 2018).

For family businesses that would like to hand over control to the next generation, fewer children may generate problems. As internal succession is still the preferred option by many family businesses (Royer et al., 2008), having fewer children means that the pool of family human capital available is reduced. Having more children creates competition for position and allows family businesses to select the most talented family heir (Madison et al., 2018). Past research indicates that limiting the pool of heirs has negative implications for family firms. Calabrò et al. (2018) show that limiting the choice of successor to the first-born child leads to negative performance consequences. In addition, it is suggested that automatic transfer of power might induce family serving behaviors at the expense of the firm. Studying the consequences of the one-child policy in China, Cao et al. (2015) found that having fewer children tempers family reinvestment in the firm, limits research and development expenses, and lowers the likelihood of an initial public offering.

Having fewer children may also have positive implications. In terms of succession, women who had previously been overlooked as suitable heirs (Stavrou, 1999) might be more considered. As the majority of family business leaders are still men, more female successors may lead to different dynamics in the succession process. Compared to father-son relationships, succession from father to daughter is hampered in terms of communication, but less plagued by conflict (Vera and Dean, 2005). As more women become family business leaders, more mothers are the ones to pass the baton to the next generation, which may lead to different dynamics in the succession process. Furthermore, a CEO who ensures family harmony is of vital importance as family firms are vulnerable to family conflicts (Harvey and Evans, 1994), which can be detrimental to the continuity of the firm. Women may be better suited to fulfill this role than men given their concerns for the family and other's needs (Curimbaba, 2002). In their roles behind the scenes, they are often seen as "Chief Emotional Officers" (Aronoff, 1998). 


\section{Changing parenting styles}

Over time, the interaction between parents and children has changed. In developed countries, children are raised in a more egalitarian and democratic environment. Research from Sweden indicates that parenting practices have become more child-oriented, authoritarian parenting styles have declined substantially and that parenting practices are more focused on the child (Trifan et al., 2014). Parents try to meet the child's needs, cultivate self-esteem and a sense of autonomy, and actively invest in the cognitive development of their child (Bernstein and Triger, 2010; Schaub, 2010). In addition, proper social and schooling systems help children to create their own career paths and to be independent of their parents.

Variance in parenting styles accounts for differential effects in child outcomes, such as in a child's skills development. Past research has shown that authoritative parenting styles, in which parents are demanding, but at the same time provide support and promote autonomy (Baumrind, 2005), predicts entrepreneurial skills and competencies among their offspring (Schmitt-Rodermund, 2004). Changes in parenting style may have consequences for the family business if children become active in the business and express these skills and behaviors through management positions. Kidwell et al. (2018) suggest that the way founders relate to their parents has a lasting impact on the human resource practices in the family business. A family culture that is infused with entitlement would lead to less formalized HR practices for non-family employees.

The fact that children have more freedom to choose their own path may further contribute to the reduced number of family successors available. Taking over the family business is not an obvious career choice and the next generation often has less interest to succeed (Sieger et al., 2016). It is therefore important for family businesses to start thinking and talking about succession a long time before the actual process of succession starts. If it becomes clear that the next generation wants to succeed, an appropriate training and development program should be developed in order to ensure a smooth transition (Cabrera-Suárez et al., 2001). Otherwise, alternative options such as employing an external director or even selling the business need to be explored. 


\section{A myriad of family structures}

Over time, society has shaped new views on what a family constitutes, leading to different family structures and a change in family stability.

\section{Diversity of family structures}

The "traditional" nuclear family comprising a married husband and wife with children is losing prominence as the dominant family structure. Family structures have become more heterogeneous. Single parent, blended families, cohabiting couples, and same-sex couples are more common in our contemporary society. Approximately 50 percent of US adults were married in 2016 compared to 72 percent in 1960 (Parker and Stepler, 2017). Especially, younger adults are less likely to get married and continue cohabitation instead (Guzzo, 2014).

Different family structures may also create heterogeneity among family businesses. In stepfamilies, the natural tendency is to favor biological ties over non-biological ties (Jennings et al., 2018), affecting the dynamics between family members who participate in the family business. This may give rise to issues of fairness between natural heirs and stepchildren. Adequate succession planning, in terms of management and ownership, becomes more critical in such cases in order to prevent conflicts. Same-sex partnerships may face succession problems as a consequence of childlessness, but adoption is a possible solution for these couples. In Japan, adopted heirs is a common practice due to traditional male successions (Wong et al., 1992). Family businesses run by these adopted heirs outperform blood heirs due to a better selection process (Mehrotra et al., 2013). The diversity in family composition makes family business more complex, creating additional and different tensions on top of traditional family issues. Nevertheless, non-biological relatives enlarge the pool of human capital available to the firm.

\section{Changing family stability}

The myriad of family structures has created more instability when children grow up, especially due to family transitions. Improved living standards have altered people's perspectives on personal relationships and caused an increase in divorces over time. However, in line with the decrease in marriages, this increase has been halted or reversed in some countries (OECD, 2019). Nevertheless, the cohabiting alternative tends to be less stable than it used to be (Guzzo, 2014). 
Although separations create periods of heightened instability in the family (Patterson, 2002), they also have consequences for family involvement, viability, and the relational capital of the business. When the business is family owned, Galbraith (2003) found that divorce negatively affects the family business' short-term performance - not only due to firm assets being divided, but the family also needs to reorganize itself. If both partners work in the business, separation does not necessarily mean the end but several emotional factors are important for continuing the business relationship successfully, amongst which having trust in each other was found to be the most important (Cole and Johnson, 2007). In addition, family social capital, arising from stability, interdependence and interactions, affects the development of organizational social capital (Arregle et al., 2007). Children from intact families are found to have better relationships with their parents, exhibit less problematic behaviors, and perform better at school (Brown, 2010). Hence, different family compositions and family shocks may affect family social and human capital.

\section{Changing intergenerational dynamics}

The final section of this chapter describes trends related to intergenerational dynamics, which are important for family businesses because multiple generations work together.

\section{Increased life expectancy}

Life expectancy has increased significantly. Currently, the average life expectancy in Europe is 80.6 years (Eurostat, 2019), while in 1900, the average age in the Western world was approximately 40 years (Roser et al., 2013).

As people become older, family business leaders may stay even longer at the helm. In contrast to other organizational forms, family leaders often have a longer tenure (Schulze et al., 2003) and find it hard to pass the firm on to subsequent generations (Handler, 1994). Increased tenure may affect management behaviors, especially in relation to innovative practices. Inherent to long tenure is the risk of inertia, making it more difficult for the CEO to adapt to the environment (Miller, 1991).

The increasing tenure also has important implications for succession in terms of successor availability and quality of the succession process. If the family business leader stays longer in the business, it may be possible that succession skips one generation. The next generation - with potentially many good 
ideas about running the family business - will start looking for other opportunities if they have to wait too long (Jaffe, 2018). Different family dynamics between grandparents and grandchildren may alter the succession process. Grandparents are not responsible for the children's upbringing, removing tensions that often exist between parents and children (Aldous, 1996). This could make family succession among parents and grandchildren easier. Increased life expectancy may also have implications for the governance of the family business. More generations are working together in the family business and Lambrecht and Lievens (2008) state that each generation adds complexity to the family business. Managing multiple generations in a family is complex because family members from different generations may own and manage the firm together. The owning family members might have opposing views on doing business, differ in skills and capabilities or commitment to the firm. Simplifying ownership, management, and governance structures in term of family involvement is found to be a beneficial solution in order to sustain family harmony and firm performance (Lambrecht and Lievens, 2008).

\section{Different generations, different characteristics}

Generations are characterized by similar societal experiences during their upbringing, leading to similarities in values, norms, attitudes, and behavior, and affecting all aspects of life including the workplace.

Generational differences may lead to different family firm behaviors as Millennials start to lead the family business. This generation grew up in a digital era, has different communication and management styles, and attaches more importance to work-life balance (Anderson et al. 2017). The altered work-life balance may diminish the emphasis on the business. Basco and Pérez Rodríguez (2011) demonstrate that attaching value to both the family and business in decision-making leads to better business performance. As roles are highly integrated, it is hard for family members in a family firm to separate family and business roles (Ashforth, 2000). Ensuring a good work-life balance thus needs conscious management of both roles and clear expectations among family members. Furthermore, the more participative leadership style of Millennials (Chou, 2012) may mitigate against the detrimental tendency of family firms to favor family employees over non-family employees (Verbeke and Kano, 2012), as feedback and involvement of employees is valued more.

Family firms need to consider and appreciate generational differences in the succession process. Different values and norms can contribute to conflicts between successors and predecessors in the firm regarding the strategy and management of the firm. For instance, Millennials may prefer to use different 
media to communicate with the firm's stakeholders than previous generations who generally value face-to-face contact for doing business.

\section{Conclusion and future research directions}

This chapter highlights the uniqueness of family businesses that arises from the interaction of the family system with the business. Through management and ownership positions, peculiarities of the family system flow into the business. The family system is not static and tomorrow's family business will be different from today's. In this chapter, trends in the family system and consequences for the way family businesses are owned, managed, and transferred to the next generation are described. While the list of trends, nor its implications, are exhaustive, it shows the importance of the nature of the family system for family business research. The changing nature of the family offers fruitful new research opportunities. Building on past research, five interesting avenues are proposed.

Firstly, several trends imply that within-family succession may become more problematic in the near future due to a decrease in the number of children and changed career perspectives. An interesting avenue is to examine what factors drive the intention to become active in the firm and their consequences. Willingness and motivation of the successor are important factors for an effective succession (Le Breton-Miller et al., 2004). Family dimensions may be a driver, as families have a strong influence on their children's career choice in general. Drivers of intention to succeed may lead to different behaviors in the firm. In families with few successors, children may feel the pressure of the previous generations to continue the family business. This could result in a lower sense of psychological ownership, which in turn hampers the expression of stewardship behaviors (Hernandez, 2012).

Secondly, if there are no family successors the family businesses might need to divert to non-family routes of succession. A proper understanding of viable alternatives such as hiring an external director, exiting by means of a sale, IPO, or private equity are necessary. Recently, family firms and private equity parties have become more interested in each other, but not much is known about the impact of private equity on the behavior and performance of family businesses. Since family firms and private equity have different goals and values, research could examine which factors make private equity partnerships more successful. If family firms choose to transfer their business to outsiders, they lose their "family firm status," but it is unclear what makes such a tran- 
sition effective. The majority of merger and acquisition research takes the perspective of family firms as acquirer (Worek, 2017). Mickelson and Worley (2003) suggest that as targets, family firms are more complex due to the family's emotional attachment to the firm and the way family involvement affects the firm's structure and behavior. Finally, as family businesses contribute substantially to a country's economy, understanding is needed of the societal implications if many family businesses become non-family businesses.

Thirdly, the trends may alter the intrafamily succession process as the pool of family predecessors and successors changes. Succession research in family firms has mainly examined father-son dyads. A promising research avenue would be to study the implications of different types of familial bonds for the succession process and its outcomes. The succession process is a process of mutual role adjustments in which successor and predecessor work together for a considerable period (Handler, 1994) and establishing effective working relationship is important. Bird and Zellweger (2018) have shown that types of familial relationships within the nuclear family affect firm growth. Compared to the nuclear family, relationships between extended family members may be less plagued by family baggage but trust, cohesion, and commitment among these extended family members may be lower than among the nuclear family.

Fourthly, changing views on family roles and work make the balancing act between the family and the firm more prominent. Work-family conflict is heightened in a family business due to the fact that family members have dual roles, but this has not been systematically investigated. Future research could examine how family businesses manage their optimal segmentation-integration preferences and which family characteristics contribute to an optimal balance between the family and the business. Proper communication between family members may resolve differences in expectations among them and contributes to increased clarity about roles and reduced work-family conflict.

Fifthly, another option for future research would be to explore the consequences of changing family relationships for firm behavior and outcomes. Due to changed parent-child dynamics and family structures, family social capital may change as well. Arregle et al. (2007) pointed to the importance of family social capital for the firm's social capital, which is shaped by family interdependence and interactions. According to family science research, family structures affect family interactions (Brown et al., 2015). After a divorce, for example, interaction with one of the parents may decrease, but parents also relate differently to stepchildren compared to biological children. 
This chapter is limited to the influence of family trends on the family business. However, the relationship between the family and business system is reciprocal (Kepner, 1983) and scholars should therefore not neglect the impact of the business on family dimensions. Furthermore, although the trends are described separately, they are interconnected. Finally, the chapter mainly views family trends from a Western perspective. Cultural differences are certainly important, but each society tends to follow similar kinds of trends over time, depending on the stage of the economy.

Table 1.1 Future research directions

\begin{tabular}{|c|c|c|}
\hline $\begin{array}{l}\text { Research } \\
\text { Direction }\end{array}$ & $\begin{array}{l}\text { Topic/Main } \\
\text { Theme }\end{array}$ & Research Question(s) \\
\hline \multirow[t]{2}{*}{1} & \multirow{2}{*}{$\begin{array}{l}\text { Next } \\
\text { generation's } \\
\text { intention } \\
\text { to join } \\
\text { the family } \\
\text { business }\end{array}$} & $\begin{array}{l}\text { What is the impact of different family structures and } \\
\text { dynamics on the next generation's intention to join the } \\
\text { family businesses? }\end{array}$ \\
\hline & & $\begin{array}{l}\text { - How are drivers of intention to succeed related to } \\
\text { leadership and management behaviors? }\end{array}$ \\
\hline \multirow[t]{4}{*}{2} & \multirow[t]{4}{*}{$\begin{array}{l}\text { Exit } \\
\text { strategies }\end{array}$} & $\begin{array}{l}\text { - What factors make a M\&A of a family business more } \\
\text { or less successful? }\end{array}$ \\
\hline & & $\begin{array}{l}\text { - Which exit option is most suitable for the family and } \\
\text { firm and under which circumstances? }\end{array}$ \\
\hline & & $\begin{array}{l}\text { What are the implications of private equity for family } \\
\text { business behaviors and outcomes? }\end{array}$ \\
\hline & & $\begin{array}{l}\text { What factors (e.g. governance decisions, partner } \\
\text { choice) make private equity more or less successful? }\end{array}$ \\
\hline \multirow[t]{2}{*}{3} & \multirow{2}{*}{$\begin{array}{l}\text { Intrafamily } \\
\text { succession } \\
\text { process }\end{array}$} & $\begin{array}{l}\text { - What are the implications of different types of familial } \\
\text { relationships for the succession process? }\end{array}$ \\
\hline & & $\begin{array}{l}\text { - Which types of family succession are more effective } \\
\text { and under which circumstances? }\end{array}$ \\
\hline \multirow[t]{2}{*}{4} & \multirow{2}{*}{$\begin{array}{l}\text { Work- } \\
\text { family } \\
\text { issues }\end{array}$} & $\begin{array}{l}\text { - What kind of policies do family businesses use to } \\
\text { reduce work-family conflict? }\end{array}$ \\
\hline & & $\begin{array}{l}\text { - Which family characteristics contribute to or mitigate } \\
\text { work-family conflict in family firms? }\end{array}$ \\
\hline \multirow[t]{2}{*}{5} & \multirow[t]{2}{*}{$\begin{array}{l}\text { Social } \\
\text { capital }\end{array}$} & $\begin{array}{l}\text { - What are the implications of different family struc- } \\
\text { tures for the creation of social capital? }\end{array}$ \\
\hline & & $\begin{array}{l}\text { - How do family events impact family firm social } \\
\text { capital? }\end{array}$ \\
\hline
\end{tabular}




\section{Note}

1. j.j.j.kox@tilburguniversity.edu

\section{References}

Aldous, J. 1996. Family Careers: Rethinking the Developmental Perspective. Thousand Oaks, CA: Sage Publications.

Anderson, H.J., Baur, J.E., Griffith, J.A., and Buckley, M.R. 2017. What works for you may not work for (Gen) Me: Limitations of present leadership theories for the new generation. The Leadership Quarterly, 28(1): 245-260.

Aronoff, C.E. 1998. Megatrends in family business. Family Business Review, 11(3): $181-6$.

Arregle, J.L., Hitt, M.A., Sirmon, D.G., and Very, P. 2007. The development of organizational social capital: Attributes of family firms. Journal of Management Studies, 44(1): 73-95.

Ashforth, B. 2000. Role Transitions in Organizational Life: An Identity-Based Perspective. New York: Routledge.

Basco, R., and Pérez Rodríguez, M.J. 2011. Ideal types of family business management: Horizontal fit between family and business decisions and the relationship with family business performance. Journal of Family Business Strategy, 2(3): 151-65.

Baumrind, D. 2005. Patterns of parental authority and adolescent autonomy. New Directions for Child and Adolescent Development, 2005(108): 61-9.

Bernstein, G., and Triger, Z. 2010. Over-parenting. UC Davis Law Review, 44: 1221-1279.

Bird, M., and Zellweger, T. 2018. Relational embeddedness and firm growth: Comparing spousal and sibling entrepreneurs. Organization Science, 29(2): 264-83.

Brown, S.L. 2010. Marriage and child well-being: Research and policy perspectives. Journal of Marriage and Family, 72(5): 1059-77.

Brown, S.L., Manning, W.D., and Stykes, J.B. 2015. Family structure and child wellbeing: Integrating family complexity. Journal of Marriage and Family, 77(1): 177-90.

Cabrera-Suárez, K., Saá-Pérez, P., and García-Almeida, D. 2001. The succession process from a resource- and knowledge-based view of the family firm. Family Business Review, 14(1): 37-48.

Calabrò, A., Minichilli, A., Amore, M.D., and Brogi, M. 2018. The courage to choose! Primogeniture and leadership succession in family firms. Strategic Management Journal, 39(7): 2014-35.

Cao, J., Cumming, D., and Wang, X. 2015. One-child policy and family firms in China. Journal of Corporate Finance, 33: 317-29.

Carr, A. 2000. Family Therapy: Concepts, Process and Practice. New York: John Wiley and Sons.

Chou, S.Y. 2012. Millennials in the workplace: A conceptual analysis of millennials' leadership and followership styles. International Journal of Human Resource Studies, 2(2): 71-83.

Cole, P., and Johnson, K. 2007. An exploration of successful copreneurial relationships postdivorce. Family Business Review, 20(3): 185-98. 
Cox, M.J., and Paley, B. 1997. Families as systems. Annual Review of Psychology, 48(1): 243-67.

Curimbaba, F. 2002. The dynamics of women's roles as family business managers. Family Business Review, 15(3): 239-52.

Davis, P. 1983. Realizing the potential of the family business. Organizational Dynamics, 12(1): 47-56.

Eichelsheim, V.I., Deković, M., Buist, K.L., and Cook, W.L. 2009. The social relations model in family studies: A systematic review. Journal of Marriage and Family, 71(4): 1052-69.

Eurostat. 2019. People in the EU - Statistics on demographic changes, January 4. Accessed September 9, 2019 at https://ec.europa.eu/eurostat/statistics-explained/ index.php?title=People_in_the_EU_-_statistics_on_demographic_changes\&oldid= 417733\#EU_population_structure_and_historical_developments.

Galbraith, C.S. 2003. Divorce and the financial performance of small family businesses: An exploratory study. Journal of Small Business Management, 41(3): 296-309.

Guzzo, K.B. 2014. Trends in cohabitation outcomes: Compositional changes and engagement among never-married young adults. Journal of Marriage and Family, 76(4): 826-42.

Hambrick, D.C., and Mason, P.A. 1984. Upper echelons: The organization as a reflection of its top managers. Academy of Management Review, 9(2): 193-206.

Handler, W.C. 1994. Succession in family business: A review of the research. Family Business Review, 7(2): 133-57.

Harvey, M., and Evans, R.E. 1994. Family business and multiple levels of conflict. Family Business Review, 7(4): 331-48.

Hernandez, M. 2012. Toward an understanding of the psychology of stewardship. Academy of Management Review, 37(2): 172-193.

Jaffe, D. 2018. Stepping up: What family business leaders can do after the step down. Forbes, November 15. Accessed October 7, 2019 at https://www.forbes.com/sites/ dennisjaffe/2018/11/15/stepping-up-what-family-business-leaders-can-do-after -they-step-down/\#39aaf5617e53.

Jennings, J.E., Dempsey, D., and James, A.E. 2018. Bifurcated HR practices in family firms: Insights from the normative-adaptive approach to stepfamilies. Human Resource Management Review, 28(1): 68-82.

Kepner, E. 1983. The family and the firm: A coevolutionary perspective. Organizational Dynamics, 12(1): 57-70.

Kidwell, R.E., Eddleston, K.A., and Kellermans, F.W. 2018. Learning bad habits across generations: How negative imprints affect human resource management in the family firm. Human Resource Management Review, 28(1): 5-17.

Klein, D., and White, J. 1996. Family Theories: An Introduction. Thousand Oaks, CA: Sage Publications.

Lambrecht, J., and Lievens, J. 2008. Pruning the family tree: An unexplored path to family business continuity and family harmony. Family Business Review, 21(4): 295-313.

Le Breton-Miller, I.L., Miller, D., and Steier, L.P. 2004. Toward an integrative model of effective FOB succession. Entrepreneurship Theory and Practice, 28(4): 305-28.

Madison, K., Daspit, J.J., Turner, K., and Kellermanns, F.W. 2018. Family firm human resource practices: Investigating the effects of professionalization and bifurcation bias on performance. Journal of Business Research, 84: 327-336. 
Mehrotra, V., Morck, R., Shim, J., and Wiwattanakantang, Y. 2013. Adoptive expectations: Rising sons in Japanese family firms. Journal of Financial Economics, 108(3): 840-54.

Mickelson, R.E., and Worley, C. 2003. Acquiring a family firm: A case study. Family Business Review, 16(4): 251-68.

Miller. D. 1991. Stale in the saddle: CEO tenure and the match between organization and environment. Management Science, 37(1), 34-52.

Murray, C.J., Callender, C.S., Kulikoff, X.R. et al. 2018. Population and fertility by age and sex for 195 countries and territories, 1950-2017: A systematic analysis for the Global Burden of Disease Study 2017. The Lancet, 392(10159): 1995-2051.

OECD. 2019. Marriage and divorce rates, June 30. Accessed October 7, 2019 at https:// www.oecd.org/els/family/SF_3_1_Marriage_and_divorce_rates.pdf.

Olson, D.H. 2000. Circumplex model of marital and family sytems. Journal of Family Therapy, 22(2): 144-67.

Parker, K., and Stepler, R. 2017. As US marriage rate hovers at 50\%, education gap in marital status widens, September 14, Pew Research Center. Accessed October 7, 2019 at https://www.pewresearch.org/fact-tank/2017/09/14/as-u-s-marriage-rate-hovers -at-50-education-gap-in-marital-status-widens/.

Patterson, J.M. 2002. Understanding family resilience. Journal of Clinical Psychology, 58(3): 233-46.

Roser, M., Ortiz-Ospina, E., and Ritchie, H., 2013. Life Expectancy. Accessed June 16, 2020 at https://ourworldindata.org/life-expectancy.

Royer, S., Simons, R., Boyd, B., and Rafferty, A. 2008. Promoting family: A contingency model of family business succession. Family Business Review, 21(1): 15-30.

Schaub, M. 2010. Parenting for cognitive development from 1950 to 2000: The institutionalization of mass education and the social construction of parenting in the United States. Sociology of Education, 83(1), 46-66.

Schmitt-Rodermund, E. 2004. Pathways to successful entrepreneurship: Parenting, personality, early entrepreneurial competence, and interests. Journal of Vocational Behavior, 65(3): 498-518.

Schulze, W.S., Lubatkin, M.H., and Dino, R.N. 2003. Exploring the agency consequences of ownership dispersion among the directors of private family firms. Academy of Management Journal, 46(2): 179-94.

Sieger, P., Fueglistaller, U., and Zellweger, T. 2016. Student entrepreneurship 2016: Insight from 50 countries. St. Gallen/Bern: KMU-HSG/IMU.

Stavrou, E.T. 1999. Succession in family businesses: Exploring the effects of demographic factors on offspring intentions to join and take over the business. Journal of Small Business Management, 37(3): 43-61.

Trifan, T.A., Stattin, H., Tilton-Weaver, L. 2014. Have authoritarian parenting practices and roles changes in the last 50 years? Journal of Marriage and Family, 76(4): 744-61.

Vera, C.F., and Dean, M.A. 2005. An examination of the challenges daughters face in family business succession. Family Business Review, 18(4): 321-45.

Verbeke, A., and Kano, L. 2012. The transaction cost economics theory of the family firm: Family-based human asset specificity and the bifurcation bias. Entrepreneurship Theory and Practice, 36(6): 1183-205.

Wong, B., McReynolds, B.S., and Wong, W. 1992. Chinese family firms in the San Francisco Bay area. Family Business Review, 5(4): 355-72.

Worek, M. 2017. Mergers and acquisitions in family businesses: Current literature and future insights. Journal of Family Business Management, 7(2): 177-206. 
Joyce Kox and Astrid Kramer - 9781788974073 Downloaded from PubFactory at $04 / 26 / 2023$ 04:11:22AM via free access 